\title{
KOMPENZATORNE STRATEGIJE U RAZVIJANJU JEZIČKE VEŠTINE SLUŠANJA U NASTAVI ENGLESKOG JEZIKA - KVALITATIVNO ISTRAŽIVANJE
}

\begin{abstract}
APSTRAKT: Jezička veština slušanja sa razumevanjem podrazumeva procese koji iziskuju veliki mentalni napor. Ipak, razvijanje ove veštine kod učenikâ olakšano je upotrebom strategija za učenje stranog jezika, naročito kompenzatornih strategija. Stoga, ciljevi kvalitativnog istraživanja su: utvrditi da li su učenici upoznati sa kompenzatornim strategijama i doći do saznanja da li i kako ih učenici koriste prilikom rešavanja konkretnih zadataka slušanja sa razumevanjem. Istraživanje je sprovedeno na uzorku od 7 učenika šestog razreda osnovne škole sa naprednim znanjem engleskog jezika. Za prikupljanje podataka korišćen je intervju i protokol razmišljanja naglas. Podaci istraživanja analizirani su metodom analize sadržaja. Rezultati istraživanja pokazuju da učenici sa naprednim znanjem engleskog jezika koriste kompenzatorne strategije, ali da nemaju svesti o njima niti znanje o tome koliko im one mogu pomoći u savladavanju veštine slušanja. Pedagoške implikacije ovog rada odnosile bi se na obuku učenika kompenzatornim strategijama kako bi razvili veštinu slušanja sa razumevanjem.
\end{abstract}

Ključne reči: kompenzatorne strategije, veština slušanja, kvalitativno istraživanje, nastava engleskog jezika.

\section{COMPENSATION STRATEGIES IN DEVELOPING THE LANGUAGE SKILL OF LISTENING IN TEACHING THE ENGLISH LANGUAGE - QUALITATIVE RESEARCH}

ABSTRACT: The language skill of listening comprehension implies the processes that require great mental effort. Nevertheless, the development of this skill is facilitated for students by the use of language learning strategies, especially compensation strategies. Therefore, the aims of the qualitative research are to determine the students' familiarity with compensation strategies and to discover whether and how the students use them while solving concrete tasks of listening comprehension. The research has been conducted on the sample of 7 sixth-grade students of primary school with advanced knowledge of English. The author has collected data using the methods of interview and think-aloud protocol. The research data have been analysed with the method of content analysis. The results of the research show that the students with advanced knowledge of English use compensation strategies, but they are not aware of them and they do not know how much the strategies can help them in mastering the listening skill. The pedagogical implications of this paper would refer to the training of students on compensation strategies so as to develop the listening comprehension skill.

Key words: compensation strategies, listening skill, qualitative research, teaching English. 


\section{UVOD}

S obzirom na to da je učenje stranog jezika jedan složen i dugotrajan proces, u najranijoj fazi ovog procesa neophodno je što više razvijati veštinu slušanja jer, kao i u maternjem jeziku, naša uloga slušalaca prethodi ulozi govornika. Slušanje sa razumevanjem podrazumeva aktivne i svesne procese koji iziskuju veliki mentalni napor. Naučiti učenike kako da slušaju sa razumevanjem jedan je od najtežih i najvažnijih zadataka svakog nastavnika. Razvijanje i ovladavanje ovom veštinom je u velikoj meri olakšano primenom strategija za učenje stranog jezika. Neophodno je da učenik prvo poznaje strategije, a potom da nauči da ih koristi.

\section{TEORIJSKI OKVIR}

Strategije za učenje (engl. learning strategies) pronalaze svoje teorijsko uporište u okviru kognitivne teorije učenja, koja se u velikoj meri oslanja na teoriju obrade informacija. Ova teorija posebno naglašava aktivnu ulogu učenika u traženju načina razumevanja, obrade i povezivanja primljenih informacija sa onim što je već poznato i uskladišteno u memoriji. Stoga, posmatrano sa stanovišta kognitivne teorije obrade informacija, O'Mali i Šamo (O'Malley i Chamot 1990: 1) definišu strategije za učenje kao „posebne misli ili ponašanja koja pojedinci koriste kako bi pomoću njih razumeli, naučili i zapamtili nove informacije”. Pomenuti autori navode da strategije za učenje mogu preći u proceduralno znanje uz pomoć vežbe i da, kao i ostale složene kognitivne veštine, mogu proći kroz tri faze učenja: kognitivnu, asocijativnu i autonomnu (O’Malley i Chamot 1990: 85). Iz navedenog sledi da učenik može svesno da koristi strategije tokom ranih faza učenja, a kasnije, kada pređu u autonomnu fazu, da ih primenjuje automatski. U procesu kognitivnog učenja strategije za učenje čine eksplicitnim ono što bi inače moglo da se dogodi bez učenikove svesti o tome ili što bi bilo bezuspešno, a što može da ima za rezultat nepotpuno skladištenje informacija u dugoročnoj memoriji (Pavičić Takač 2008: $30)$.

Usvajanje jezika kao mentalni proces uključuje strategije koje objašnjavaju na koji način se znanje stranog jezika razvija i koristi u komunikaciji (Ellis 1995, prema Pavičić Takač 2008: 29).

Najdetaljniji opis i podelu strategija daje Oksford (Oxford 1990: 14), koja ih svrstava u dve velike grupe: direktne (engl. direct) i indirektne (engl. indirect). Jedna grupa direktnih strategija, pod nazivom kompenzatorne strategije (engl. compensation strategies), pomaže učenicima da prevaziđu ograničenja sa kojima se susreću prilikom učenja stranog jezika. Prva podgrupa kompenzatornih strategija, inteligentno pogađanje (engl. guessing intelligently), odnosi se na veštinu slušanja sa razumevanjem. Inteligentno pogađajući reči i strukture koje ne znaju, učenici koriste jezičke signale i indikatore i ostale siginale i indikatore. Jezički signali i indikatori se odnose na prethodno znanje ciljnog jezika, maternjeg ili nekog drugog 
jezika (Oxford 1990: 90-94). Ostali signali i indikatori su vanjezički i uključuju poznavanje konteksta, situacije, strukture teksta, ličnih odnosa, teme ili „opšteg znanje o svetu" (Oxford 1990: 49-50).

Upotreba kompenzatornih strategija u učenju stranog jezika prilikom savladavanja jezičke veštine slušanja sa razumevanjem predstavlja predmet našeg istraživanja. Ovaj rad će pokušati da pruži jasniji uvid u to da li su učenici šestog razreda sa naprednim znanjem engleskog jezika upoznati sa kompenzatornim strategijama, tj. sa inteligentnim pogađanjem, podgrupom koja se odnosi na veštinu slušanja, koliko su svesni činjenice da im kompenzatorne strategije mogu pomoći u rešavanju problema u razumevanju jezika, kao i to da li ih i kako koriste prilikom rešavanja zadataka slušanja sa razumevanjem.

\section{RANIJA ISTRAŽIVANJA U SVETU I KOD NAS}

Veština slušanja je dugo zanemarivana $u$ istraživanjima u odnosu na ostale tri veštine: govor, čitanje i pisanje. Stoga je neki autori nazivaju „Pepeljugom” (Flowerdew \& Miller 2005: xi). Uzrok nepravednog zanemarivanja ove veštine u istraživanjima možda leži u činjenici da nije moguće posmatrati procese koji se odvijaju kod ispitanika/učenika prilikom slušanja, niti je moguće imati direktan uvid $u$ njih. Rezultat i zaključak istraživanja u najvećoj meri zavise od ispitanikovog/učenikovog subjektivnog doživljaja i od njegove/njene sposobnosti da objasni pomenute procese. Međutim, proteklih nekoliko godina istraživači počinju sve više da se bave ovom veštinom i to u kontekstu strategija učenja stranog jezika. Stoga istraživači razvijaju strategije slušanja sprovodeći različita istraživanja kako bi utvrdili i rešili probleme sa kojima se učenici, odnosno studenti susreću.

Osamdesetih godina Marfi (Murphy 1985) sprovodi istraživanje o strategijama slušanja na engleskom jeziku u kojem pokazuje da napredniji studenti kojima engleski jezik nije maternji slobodnije i fleksibilnije koriste strategije, dok se manje napredni studenti više oslanjaju na tekst. Čen (Chen 2005) primenjuje tehniku razmišljanja naglas u jednoj svojoj studiji i identifikuje pet delotvornih strateških šablona koje koriste slušaoci engleskog jezika kao stranog, a u drugoj studiji se bavi preprekama u usvajanju strategija slušanja kod studenata. Liu (Liu 2008) istražuje odnos između korišćenja strategija slušanja, nivoa savladanosti slušanja i stila učenja. Postoji i studija o uticaju programa obuka o upotrebi strategija sa ciljem da se razvije veština slušanja sa razumevanjem kod studenata koji uče engleski jezik kao strani (Attia 2002). Vandergrift (Vandergrift 2003) se dugi niz godina bavi veštinom slušanja i u jednoj od svojih studija ispituje odnos između savladanosti slušanja i upotrebe strategija slušanja. Metoda razmišljanja naglas primenjuje se $\mathrm{u}$ istraživanju problema sa kojima se susreću studenti prilikom slušanja sa razumevanjem i strategija koje koriste u raznim fazama razumevanja (Ghoneim 2013). Od osamdesetih godina do danas broj istraživača koji se bave strategijama slušanja sve je veći (Mendelsohn 1984, 1994, 1995; Anderson \& Lynch 1988; Bacon 1992; Rubin 1994; Buck 2001; Goh 2002; Brown 2006, itd.). 
Zaključuje se da u svetu postoje istraživanja na temu strategija slušanja sa razumevanjem unutar kojih se nalaze i kompenzatorne strategije, a tehnika razmišljanja naglas se pokazala kao veoma koristan metod u proučavanju veštine slušanja i strategija učenja stranog jezika.

Kod nas se, Mićić i Čajka (2013) bave strategijama slušanja u visokoškolskom obrazovanju. U našoj zemlji se sprovodi sve više istraživanja o strategijama učenja jezika primenjenih na ostale tri jezičke veštine. Topalov (2012) se bavi strateškom kompetencijom čitanja, Votls (2012) strategijom samoregulacije u razvijanju veštine pisanja, dok Knežević (2012) piše o kognitivnim i metakognitivnim strategijama u usmenom izlaganju. Strategijama se bave i Ćirković-Miladinović (2012) koja proučava afektivne strategije, dok Radić-Bojanić (2012) proučava društvene strategije u usvajanju metaforičkog vokabulara engleskog jezika. U našoj zemlji, međutim, skoro da nema obimnijih studija koje razmatraju strategije slušanja. Otuda se javila i potreba za istraživanjem na tu temu.

\section{METODOLOGIJA ISTRAŽIVANJA}

\subsection{Ciljevi istraživanja}

Ciljevi ovog istraživanja jesu da utvrdi da li su učenici šestog razreda osnovne škole sa naprednim znanjem engleskog jezika upoznati sa kompenzatornim strategijama (prva faza istraživanja) i da dođe do podataka i saznanja da li i kako ovi učenici koriste kompenzatorne strategije prilikom rešavanja konkretnih zadataka slušanja sa razumevanjem (druga faza istraživanja).

\subsection{Ispitanici}

Autorka se odlučila za odlučila za namerno odabrani uzorak, jer će ovakav odabir ispitanika najviše doprineti ostvarivanju ciljeva istraživanja. Ovakva vrsta uzorka odnosi se na odabir slučajeva koji će pružiti obilje informacija u vezi sa pitanjima koja su od važnosti za cilj istraživanja (Patton 2002: 230).

U celokupnom istraživanju učestvovalo je sedam ispitanika, učenika iz dva odeljenja šestog razreda osnovne škole „Dositej Obradović” u Opovu. Među njima je bilo četiri dečaka i tri devojčice. Svim učenicima je engleski jezik prvi strani jezik koji uče od prvog razreda osnovne škole. Nivo znanja engleskog jezika ispitanika/učenika je napredan, a određen je srednjom ocenom iz prethodne školske godine, što znači da svih sedam učenika poseduje približno isti nivo znanja engleskog jezika. Ovi učenici su više motivisani da uče engleski jezik i u toku časova su najaktivniji, žele da što više nauče i napreduju. Iako je uzorak u istraživanju relativno mali, što onemogućava generalizovane zaključke, cilj ovog istraživanja nije u tome da se postigne reprezentativnost, već dubinsko razumevanje fenomena (Patton 2002: 46). 


\subsection{Instrument i procedura}

U cilju dobijanja podataka u istraživanju kao instrument korišćen je intervju i protokol razmišljanja naglas (engl. think-aloud protocol). U prvoj fazi istraživanja korišćen je polustrukturisani intervju (engl. semi-structured interview) sa pripremljenim pitanjima koja su poslužila kao osnova za vođenje razgovora. Pitanja su sačinjena na osnovu taksonomije strategija za učenje stranog jezika koju daje Oksford (Oxford 1990: 90-94). Uzimajući u obzir nivo znanja učenika, intervjui su sprovedeni na maternjem jeziku ispitanika, tj. na srpskom jeziku. Pre početka intervjua, učenici su informisani u vezi sa ciljem ovog istraživanja kako bi bez straha i iskreno odgovarali na postavljena pitanja. Intervjui su u proseku trajali 20 minuta i obavljani su nakon redovnih časova.

Druga faza istraživanja obuhvatala je intervju primenom protokola razmišljanja naglas. Ova metoda predstavlja jedinstveni izvor informacija o kognitivnim procesima (Van Someren i sar. 1994: xi). Dalje, ovi autori objašnjavaju da je cilj ovog metoda da objasni skoro svaki korak koji preduzima osoba koja rešava problem. Cilj je da se onaj koji intervjuiše što više približi činu obavljanja zadatka (Patton 2002: 385). Upotreba navedene metode naročito može da bude delotvorna u obrazovnom kontekstu kako bi se došlo do saznanja o poteškoćama sa kojima se učenici susreću prilikom rešavanja problema, odnosno zadataka. Autorka je odlučila da koristi istovremeni protokol razmišljanja naglas (engl. concurrent think-aloud protocol) kako bi učenici tokom rešavanja zadatka odmah objasnili način na koji su to obavili. Kod testa slušanja je to rešeno tako što su učenici u svakom trenutku mogli da zaustave snimak kako bi rešili zadatak i opisali kako su to učinili. Test slušanja sa razumevanjem sastojao se iz dva kraća snimka u trajanju od 2 minuta (u proseku), podjednake težine u vezi sa dve različite situacije. Materijal slušanja sastojao se od dijaloga. Oba snimka su delovi testa ${ }^{1}$ višeg nivoa za sedmi razred, što znači da je jezički input prema Krašenovoj hipotezi $i+1$, malo iznad učenikovog trenutnog nivoa znanja. Glasovi sa snimka su jasni, a buka u pozadini je minimalna. Odabir odgovarajućeg testa je od presudnog značaja jer, ako je input previše složen, učenici će se obeshrabriti, a ako je previše lak, ne može se steći uvid u procese slušanja. Pre testa slušanja učenicima su data jasna uputstva da će slušati dva snimka dužine po 2 minuta $i$ da treba da reše pitanja koja su im unapred data da pročitaju. Učenicima je objašnjeno kako da verbalizuju svoje misli, što znači da je testu prethodila kratka obuka. Zadatak se sastojao od 15 pitanja na koja treba dati odgovore tačno ili netačno (engl. true or false). Učenici su trebali da odrede da li su rečenice tačne ili netačne. Tokom protokola razmišljanja naglas, od učenika-slušaoca se tražilo da opiše svoje misli u usmenoj formi tokom samog zadatka slušanja. Nekoliko puta im je autorka ponovila da treba da pričaju sve što im u tom trenutku prolazi kroz misli i da je najvažnije da se skoncentrišu na

\footnotetext{
${ }^{1}$ Test preuzet iz: English Plus Teacher's Book 3.
} 
zadatak. Odgovori učenika su snimani radi lakšeg kodiranja podataka. Autorka istraživanja povremeno je postavljala pitanja poput: „Da li si nešto učinio/la da ti pomogne da razumeš snimak u bilo kom trenutku slušanja?" sa ciljem da istraži njihove misli i kako bi učenici nastavili da usmeno verbalizuju svoje misli.

Istraživanje je sprovedeno u drugom polugodištu školske 2014/15. godine, prva faza u periodu od februara do marta, a druga faza istraživanja u periodu od aprila do juna.

Podaci dobijeni primenom intervjua i protokola razmišljanja naglas analizirani su pomoću metode analize sadržaja (engl. content analysis) da bi se dobile kategorije, tj. strategije koje će biti predstavljene u sledećem odeljku.

\section{REZULTATI ISTRAŽIVANJA}

\subsection{Prva faza istraživanja: intervju}

Pitanja iz intervjua koja su sačinjena na osnovu taksonomije strategija za učenje stranog jezika koju daje Oksford (Oxford 1990: 90-94) odnosila su se na kompenzatorne strategije koje se primenjuju u veštini slušanja, odnosno kompenzatornu strategiju pod nazivom inteligentno pogađanje (engl. guessing intelligently) koja obuhvata upotrebu jezičkih signala i indikatora i upotrebu vanjezičkih signala $i$ indikatora. Slede delovi intervjua koji predstavljaju navedene strategije.

\subsubsection{Upotreba jezičkih signala i indikatora}

Upotreba jezičkih signala i indikatora odnosi se na korišćenje znanja ciljnog, maternjeg ili nekog drugog jezika prilikom razumevanja novih reči i struktura.

Primer 1 .

Autorka: Kako ti pomaže ono što već znaš u engleskom jeziku da razumeš neku novu reč koju čuješ?

U3: Pa povežem.... Znam šta znači reč koja stoji do te reči i povežem... Uglavnom znam bar neku reč pa se tako snalazim.

U4: Kada ne znam neku reč, obično je povezujem sa rečju koja stoji pre ili posle nje. Onda tako povezujem značenje. Bude tu poznatih reči pa nije teško...

U2: Na osnovu drugih reči koje znam pogađam značenja reči koje ne znam. Gledam da li se reč koju znam odnosi na nešto pozitivno i tako zaključujem. Ako je nešto pozitivno, onda je verovatno i reč koju ne znam pozitivna pa tako zaključujem.

Iz Primera 1. se vidi da tri učenika izjavljuju da koriste svoje postojeće znanje ciljnog jezika kako bi razumeli nove reči i strukture. Primećeno je da učenici uglavnom povezuju reč koja stoji ispred ili iza reči koju ne razumeju prilikom slušanja i pokušavaju da pogode njeno značenje. 
Primer 2.

Autorka: Da li koristiš znanje svog maternjeg jezika da bi pogodio/la značenje reči koje čuješ?

U5: Pa to se podrazumeva... Da... Poneka reč iz kriminalističkih serija koje gledam je ista kao i u srpskom, na primer, reč policija je ista kao i u engleskom police... A ja to gledam bez titla.

Od sedam intervjuisanih učenika samo je jedan učenik izjavio da se oslanja na svoje znanje maternjeg jezika prilikom razumevanja novih reči i struktura.

Na pitanje koje se odnosilo na korišćenje drugih jezika (osim ciljnog i maternjeg jezika) u razumevanju novih reči i struktura, svi intervjuisani učenici su izjavili da ne koriste to znanje.

\subsubsection{Upotreba vanjezičkih signala i indikatora}

Unutar upotrebe ostalih signala i indikatora, odnosno vanjezičkih signala, nalazi se poznavanje konteksta, korišćenje opšteg znanja o svetu i ličnog iskustva, obraćanje pažnje na pozadinu prilikom razumevanja novih reči i struktura i dr.

Primer 3.

Autorka: Da li koristiš poznavanje konteksta kako bi pogodio/la značenje reči koje čuješ?

U3: Uvek kada nešto slušam zamislim situaciju u glavi. Tako sam navikla jer mnogo čitam i mnogo slušam. Nije mi teško da odmah shvatim ono što čujem i da se prebacim na to mesto. U2: Prvo slušam ključne reči i tako zaključim o čemu se radi. $\mathrm{Na}$ osnovu konteksta pogađam reči koje ne znam.

Primer 3. pokazuje način na koji učenici obraćaju pažnju na kontekst. S obzirom na to da većina učenika nije znala šta sve podrazumeva oslanjanje na kontekst, autorka je dala podrobnije objašnjenje. Svih sedmoro učenika je izjavilo da zamisli situaciju koju sluša, što im pomaže da pogode značenje reči koje ne razumeju.

\section{Primer 4.}

Autorka: Da li koristiš znanje o svetu da ti pomogne da razumeš značenje reči i struktura koje čuješ?

U5: Kada slušam neki dijalog povežem ga sa nekim filmom koji sam gledala. Sve zavisi od toga o čemu se radi u dijalogu. Najlakše je kada je u pitanju neka obična situacija iz života, nešto što nam se dešava.

Ova strategija je, kao i prethodno opisana, zastupljena među svim intervjuisanim učenicima. Učenici su odmah bili spremni i voljni da daju mnoštvo primera korišćenja opšteg znanja o svetu koje je obično bilo povezano sa njihovim životnim iskustvom. To su bili razni sadržaji nastavnog gradiva iz različitih predmeta (biologija, istorija, geografija, informatika), kao i ostali sadržaji iz svakodnevnog života (filmovi, serije, muzika, video-igrice, sport). 
Primer 5.

Autorka: Kako ti pomaže lično iskustvo da razumeš značenje neke nove reči ili strukture?

U6: ... Deca na snimku pričaju o stvarima koje su se i nama desile, na primer, na času smo slušali kako devojčica priča sa mamom o spremanju sobe... Ja se odmah setim moje sobe. U stvari, zamislim situaciju...

Kao što se primećuje u Primeru 5, učenica navodi da sve ono što čuje na času uglavnom povezuje sa ličnim iskustvom. Ono što je veoma važno jeste $\mathrm{i}$ to da učenici odmah prilikom slušanja zamisle mentalnu situaciju. Svi intervjuisani učenici su izjavili da im lično iskustvo pomaže da razumeju ono što slušaju. Ovde se u najvećoj meri pominje slušanje na časovima engleskog jezika. Vežbe slušanja sa razumevanjem u okviru nastave obuhvataju uobičajene teme sa kojima se učenici lako identifikuju jer su deo i njihovog svakodnevnog života bez obzira na to što se dve kulture razlikuju.

Primer 6.

Autorka: Da li obraćaš pažnju na pozadinu (npr. buku) prilikom slušanja?

U7: Ponekad obraćam pažnju na pozadinu, na muziku ili neke druge zvukove.

U5: Obratim pažnju kada ima neke buke jer mi je onda teže da razumem šta pričaju.

Učenici iz Primera 6. ponekad obraćaju pažnju na pozadinu onoga što slušaju, te možemo zaključiti da im buka uglavnom smeta prilikom razumevanja dijaloga. Ostali učenici koji su intervjuisani ne obraćaju pažnju na pozadinu i ona nema uticaja na razumevanje onoga što čuju.

\subsection{Druga faza istraživanja: protokol razmišljanja naglas}

Primenom metode razmišljanja naglas dobija se detaljan izveštaj učenika o njihovim misaonim procesima dok slušaju audio-snimak i rešavaju konkretne zadatke. Kompenzatorne strategije koje su predstavljene u delovima protokola razmišljanja naglas identifikovane su na osnovu pomenute taksonomije. Detaljnom analizom protokola razmišljanja naglas ostvarili su se jasniji i sveobuhvatniji uvidi $\mathrm{u}$ upotrebu kompenzatornih strategija u odnosu na intervju. Predstavljeni su delovi protokola razmišljanja naglas koji se uglavnom odnose na reči ili fraze koje su učenicima bile nepoznate, odnosno na situaciju kada je došlo do prekida u razumevanju.

\subsubsection{Upotreba jezičkih signala}

Primer 7.

Autorka: Kako znaš šta znači reč recycling?

U1: Čuo sam tu reč i poznata mi je, a i slična je kao u srpskom. Mislim da sigurno znači recikliranje... Nema šta drugo da bude... 
Učenik iz Primera 7. je čuo za reč iz zadatka, ali još nije potpuno siguran šta znači. Iako je ovaj učenik izjavio u intervjuu iz prve faze istraživanja da ne koristi znanje maternjeg jezika, prilikom rešavanja ovog zadatka oslonio se, između ostalog, i na to znanje.

\section{Primer 8.}

Autorka: Pričaj mi o čemu razmišljaš dok rešavaš taj zadatak.

$U 2$ : Ne znam šta znači reč lottery. Verovatno nešto pozitivno čim se dobija nagrada. Znam da je prize nagrada na engleskom...

Kada dolazi do prekida u razumevanju, učenik iz Primera 8. odmah preduzima korake kako bi nadomestio nedostatak svog jezičkog znanja. On to čini tako što pokušava da na osnovu već poznate reči pogodi šta znači reč koja mu je nepoznata.

\subsubsection{Upotreba vanjezičkih signala}

Primer 9.

Autorka: Na osnovu čega si zaključila da gledanje dokumentarca nije bilo dosadno?

$U 7:$ Kad je rekla tu reč, mislim da je fantastic, zvučala je da je uzbuđena, oduševljena... Na osnovu njenog osećanja sam zaključila da je uživala...

Učenica iz Primera 9. nije sigurna koju je reč čula, ali je obratila pažnju na neverbalne signale, tj. ton kojim je osoba sa audio-snimka izgovorila reč, što je bilo dovoljno da se uspešno reši zadatak. Treba uzeti u obzir da je ovo bio audio-snimak i da učenica nije imala mogućnost da vidi govornikov izraz lica i gestikulaciju.

Primer 10.

Autorka: Na koji način rešavaš zadatke?

U1: Bilo je pitanje da li je Zero Waste rijaliti šou. Zaključio sam da to nije rijaliti program već dokumentarac, jer to nije nikakvo ime za neki šou... Nekako mi se to ne uklapa... Ne ide mi sa zabavom... Čuo sam za skroz drugačije nazive...

Iz Primera 10. se vidi da učenik aktivira opšte znanje o svetu kako bi rešio zadatak. On na osnovu svog stečenog znanja o medijima uspeva da dođe do tačnog rešenja.

Primer 11.

Autorka: Na osnovu čega si zaključio da je ta rečenica netačna?

U1: Rečenica je natačna jer ne postoji samo jedna vrsta plastike... I kod nas postoji više kategorija plastike za flaše, za igračke, tvrda, meka plastika. Mi isto kao i oni, recikliramo. svetu.

Navedeni primer takođe pokazuje učenikovo oslanjanje na opšte znanje o

Primer 12.

U1: Možda je selo siromašno pa je hrana nagrada. 
U Primeru 12. učenik zna iz života da se za recikliranje nešto dobija, ali mu je nejasno zašto ljudi dobijaju hranu kao nagradu. Razmišljajući naglas, učenik pokušava da pogađa zašto se hrana dobija kao nagrada.

Primer 13.

Autorka: Pričaj mi o čemu razmišljaš dok rešavaš taj zadatak.

U2: Prvo sam slušao ključne reči, na primer, ono što se traži da bih odgovorio na glavna pitanja koja se traže... Rekla je neobičan naziv mesta što liči na Japan ili Kinu.

Učenik iz Primera 13. prvo prepoznaje ključne reči koje ga navode na ispravan zaključak, a zatim je povezao naziv mesta sa svojim već stečenim opštim znanjem o svetu.

Primer 14.

Autorka: Pričaj mi o čemu razmišljaš dok rešavaš taj zadatak.

U3: Sad sam se setila da se i kod nas reciklirala plastika... Znate ono „Čep za hendikep”... I kod nas je to aktuelno, samo što se u tom japanskom selu dobija hrana... Verovatno dobijaju hranu jer je nemaju baš mnogo... Možda je siromašno selo...

Automatski stvorivši mentalnu sliku situacije, učenica iz Primera 14. koristi svoje lično iskustvo u vezi sa recikliranjem kako bi razumela snimak, prisetivši se humanitarne akcije u školi tokom koje su se sakupljali čepovi. Isto tako, na osnovu opšteg znanja o svetu, ova učenica pretpostavlja da ljudi dobijaju hranu jer je nemaju.

Primer 15.

U4: Znam da oni ne dobijaju puno hrane pa im se zato ona daje kao nagrada. Verovatno nije napredno selo što se tiče poljoprivrede zato im je potrebna hrana... Selo nije razvijeno.

Učenica iz Primera 15. takođe koristi opšte znanje o svetu kako bi bolje razumela snimak. Ona pominje poljoprivredu jer i ona živi na selu i iz ličnog iskustva zna razliku između razvijenosti i nerazvijenosti sela.

Primer 16.

U5: Meni se desilo da sam se sudario sa biciklom pa me je i to podsetilo na njen slučaj. Zapisala je broj tablica da nađu begunca... To sam video u akcionim filmovima i serijama gde zapisuju tablice i imaju kompjutere jer je to vozilo u njihovom sistemu i nađu ga preko kompjutera.

Učenik iz Primera 16. se odmah prisetio situacije u kojoj se i sam našao. Ovde učenik koristi lično iskustvo, prvo stvorivši mentalnu sliku situacije. Potom dokazuje da koristi i opšte znanje o svetu jer je sličnu situaciju video u filmovima i serijama. 


\section{DISKUSIJA}

U ovom odeljku iznosimo razmatranja prikazanih rezultata iz prethodnog poglavlja po fazama istraživanja.

\subsection{Prva faza istraživanja}

Nalazi prve faze istraživanja pokazuju da učenici šestog razreda sa naprednim znanjem engleskog jezika koriste kompenzatorne strategije prilikom slušanja na engleskom jeziku. Međutim, korišćenje ovih strategija se odvija bez svesti o njima jer se iz intervjua zaključuje da učenici nisu upoznati sa postojanjem ovih strategija, te da ne znaju koliko im one mogu biti od pomoći da nadoknade nedostatak znanja. Važno je napomenuti da učenici pre istraživanja nisu imali nikakvu obuku o strategijama. Iz rezultata celokupnog intervjua može se zaključiti da, kada nešto ne razumeju prilikom slušanja, intervjuisani učenici se više oslanjaju na druge, nejezičke signale i indikatore. U tim situacijama više koriste drugu podgrupu inteligentnog pogađanja. Detaljna analiza intervjua pokazuje da su oslanjanje na poznavanje konteksta i opšte znanje o svetu, povezani sa ličnim iskustvom, najviše prisutni među intervjuisanim učenicima. Primećuje se da se nijedan intervjuisani učenik ne oslanja na znanje nekog drugog stranog jezika u razumevanju novih reči i struktura prilikom slušanja. Moguće objašnjenje za ovakav rezultat bi bilo da učenici šestog razreda, pored engleskog jezika, uče još samo jedan strani jezik, ruski jezik. S obzirom na to da ova dva strana jezika ne pripadaju istim granama indoevropske jezičke porodice, moguće je da učenici ne nalaze povezanost između njih.

\subsection{Druga faza istraživanja}

Kada se razmotre i analiziraju misaoni procesi prilikom rešavanja zadatka slušanja stiče se jasan uvid u upotrebe strategija od strane učenika. Učenik nailazi na prepreku u razumevanju audio-snimka, potpuno je svestan tog prekida u razumevanju i preduzima određene radnje kako bi otklonio prekid. Čim su se susreli sa nečim što nisu razumeli ili znali, svi intervjuisani učenici su odmah pokušali da nadoknade to znanje i da poboljšaju razumevanje primenjujući strategije kojih nisu ni svesni da postoje. Iz detaljne analize protokola razmišljanja naglas, nakon identifikacije kompenzatornih strategija, na osnovu učestalosti i intenziteta pojavljivanja, zaključuje se da učenici šestog razreda sa naprednim znanjem engleskog jezika najviše koriste inteligentno pogađanje sa oslanjanjem na vanjezičke signale i indikatore, tj. na opšte znanje o svetu koje je isprepleteno sa ličnim iskustvom, što su izjavili i u intervjuu. Međutim, korišćenje strategije opšteg znanja o svetu nije bilo presudno u postizanju razumevanja prilikom rešavanja zadatka slušanja, već dobro poznavanje ciljnog jezika. 


\section{ZAKLJUČAK}

Kvalitativno istraživanje predstavljeno u ovom radu imalo je za cilj da istraži da li su učenici šestog razreda sa naprednim znanjem engleskog jezika upoznati sa kompenzatornim strategijama i da li ih i kako koriste prilikom rešavanja konkretnih zadataka slušanja na stranom jeziku. Zaključuje se da, kada dođe do prekida u razumevanju, usled ograničenog znanja ciljnog jezika, u većini slučajeva, učenici aktiviraju već stečeno opšte znanje o svetu kako bi nadoknadili, odnosno kompenzovali taj nedostatak.

Iako je broj ispitanika u istraživanju relativno mali da bi se mogli izvesti generalizovani zaključci o upotrebi kompenzatornih strategija na nivou osnovne škole, ono ipak pruža delimičan uvid u njihovu upotrebu.

Nalazi prve faze istraživanja, intervjua sa učenicima sa naprednim znanjem engleskog jezika, pokazuju da oni koriste kompenzatornu strategiju inteligentnog pogađanja koja se odnosi na receptivnu veštinu slušanja sa razumevanjem. Učenici, međutim, nemaju znanje o tome koliko im ona može pomoći u savladavanju veštine slušanja. Druga faza istraživanja, protokol razmišljanja naglas, omogućila je detaljnije podatke o upotrebi kompenzatornih strategija. Na osnovu učestalosti pojavljivanja strategije i intenziteta njene zastupljenosti, može se zaključiti da intervjuisani učenici najviše koriste vanjezičke signale i indikatore, tj. opšte znanje o svetu u kombinaciji sa ličnim iskustvom.

Uzimajući u obzir rezultate celokupnog istraživanja, može se zaključiti da se u osnovnim školama ne posvećuje pažnja kompenzatornim strategijama učenja stranog jezika, ne samo prilikom razvijanja veštine slušanja nego i uopšte. Isto tako, nastavnici u osnovnim školama više razvijaju veštinu slušanja u nižim razredima, dok kasnije u prvi plan stavljaju produktivne jezičke veštine: govor i pisanje. Stoga se javlja potreba da se kod učenika razvije svest o važnosti uloge koju ova „Pepeljuga” među veštinama ima u izgradnji komunikativne kompetencije, kao i o načinu, u ovom slučaju su to kompenzatorne strategije, na koji se ona razvija.

U Pravilniku o nastavnom planu i programu za šesti razred osnovnog obrazovanja i vaspitanja (Službeni glasnik RS - Prosvetni glasnik, br. 5/2008, 3/2011, 1/2013 i 5/2014) kod operativnih zadataka po jezičkim veštinama, zajedno sa znanjem o jeziku pojavljuju se i kompenzacione strategije, od kojih se strategije pod rednim brojem 1, 2. i 5. odnose na razvijanje veštine slušanja. Nailazimo na to da učenik primenjuje kompenzacione strategije $\mathrm{i}$ to tako što:

1. usmerava pažnju, pre svega, na ono što ne razume;

2. pokušava da odgonetne značenje na osnovu konteksta i proverava nekog ko dobro zna (druga, nastavnika, itd.);

5. razmišlja da li određena reč koju ne razume liči na neku koja postoji u maternjem jeziku. 
Međutim, navedene strategije nisu deo operativnih zadataka veštine Razumevanja govora. Otuda potreba da se i veština slušanja i kompenzatorne strategije, koje se primenjuju u savladavanju ove veštine, izvuku iz zapećka i dobiju svoje mesto u nastavi engleskog jezika kako bi se unapredio obrazovno-vaspitni proces učenja stranog jezika u osnovnoj školi. Analiza rezultata istraživanja pokazala je da učenici koriste kompenzatorne strategije, ali da nemaju svest o tome. Shodno tome, ovo istraživanje ukazuje na potrebu za uvođenjem eksplicitne nastave strategija u cilju razumevanja zahtevnijih zadataka slušanja.

Značaj ovog istraživanja jeste u tome da pomogne da se podigne svest o značaju strategija i njihovom poznavanju u učenju stranog jezika i da je dugoročni cilj u nastavi jezika, kako navodi Radić-Bojanić (2013: 45), upravo to da odgovarajuća strategija postaje u potpunosti automatizovana. Značajan preduslov za uspešnu primenu strategija je upravo svest o njenoj upotrebi. Rad predstavlja još jedan doprinos $s$ obzirom na to da je proces veštine slušanja $i$ dalje velika nepoznanica i za nastavnike i za naučnike.

\section{LITERATURA}

Attia, A. E. S. (2002). The effect of a strategy-based instruction programme on developing EFL listening comprehension skills. Doctoral thesis. University of Warwick. Pristupljeno 15.8.2015.

URL:<http://wrap.warwick.ac.uk/3050/1/WRAP_THESIS_AbdElAl_2002.pdf> Anderson, A. \& Lynch, T. (1988). Listening. Oxford: Oxford University Press.

Bacon, S. M. (1992). "The relationship between gender, comprehension, processing strategies, and cognitive and affective response in foreign language listening". The modern language journal 76 (2): 160-178.

Brown, S. (2006). Teaching Listening. Cambridge: Cambridge University Press. Buck, G. (2001). Accessing Listening. Cambridge: Cambridge University Press.

Chen, Y. (2005). "Barriers to Aquiring Listening Strategies for EFL Learners and Their Pedagogical Implications". TESL-EJ 8(4): 1-20.

Ćirković-Miladinović, I. (2012). "Primena afektivnih strategija za učenje stranog jezika na nematičnim fakultetima", u Strategije i stilovi u nastavi engleskog jezika, ur. B. Radić-Bojanić (Novi Sad: Filozofski fakultet): 73-90.

Dignen, S., Watkins, E. \& Mare, de la C. (2011). English Plus, Teacher's Book 3. Oxford: Oxford University Press.

Flowerdew, J. \& Miller, L. (2005). Second Language Listening: Theory and Practice. Cambridge: Cambridge University Press.

Ghoneim, M. (2013). "The Listening Comprehension Strategies Used by College Students to Cope with the Aural problems in EFL Classes: An Analytical Study". English Language Teaching 6, 2: 100-112.

Goh, C. (1997). "Metacognitive awareness and second language listeners". ELT Journal 51 (4): 361-369.

Goh, C. (2002). "Exploring listening comprehension tactics and their interaction 
patterns". System 30 (2): 185-206.

Knežević, Lj. (2012). „Kognitivne i metakognitivne strategije u funkciji bolje organizacije usmenih izlaganja studenata", u Strategije $i$ stilovi u nastavi engleskog jezika, ur. B. Radić-Bojanić (Novi Sad: Filozofski fakultet): 5972.

Liu, H. (2008). "A Study of the Interrelationship between Listening Strategy Use, Listening Proficiency and Learning Style". ARECLS 8: 84-104.

Mendelsohn, D. J. (1984). "There ARE strategies for listening". TEAL Ocassional Papers 8: 63-76.

Mendelsohn, D. J. (1994). Learning to listen: A strategy-based approach for the second-language learner. San Diego: Dominie Press.

Mendelsohn, D. J. (1995). "Applying learning strategies in the second/foreign language listening comprehension lesson", in A guide for the teaching of second language listening, ed. D. J. Mendelsohn \& J. Rubin (San Diego: Dominie Press): 186-221.

Mićić, S., Čajka, Z. (2013). "Listening Strategies in Language Learning and Their Teaching Practice in Serbia". Nasleđe 25: 147-159.

Murphy, J. M. (1985). An investigation into the Listening Strategies of ESL College Students. Unpublished doctoral dissertation. New York: Columbia University.

Pristupljeno 20.8.2015.

URL: 〈https://files.eric.ed.gov/fulltext/ED278275.pdf>

O’Malley, J. M., \& A. U. Chamot. (1990). Learning Strategies in Second Language Acquisition. Cambridge: Cambridge University Press.

Oxford, R. L. (1990). Language learning strategies: What every teacher should know. New York: Newbury House/Harper \& Row.

Patton, M. Q. (2002). Qualitative Research \& Evaluation Methods. Thousand Oaks, CA: Sage Publications, Inc.

Pavičić Takač, V. (2008). Vocabulary Learning and Foreign Language Acquisition. Clevedon: Multilingual Matters.

Radić-Bojanić, B. (2012). "Upotreba društvenih strategija u usvajanju metaforičkog vokabulara engleskog jezika", u Strategije i stilovi u nastavi engleskog jezika, ur. B. Radić-Bojanić (Novi Sad: Filozofski fakultet): 91-102.

Radić-Bojanić, B. (2013). Strategije za razumevanje metaforičkog vokabulara. Novi Sad: Filozofski fakultet.

Rubin, J. (1994). "A Review of Second Language Listening Comprehension Research". The Modern Language Journal 78(2): 199-221.

Pravilnik o nastavnom programu za šesti razred osnovne škole (2014). Službeni glasnik RS - Prosvetni glasnik, br. 5/2008, 3/2011 - dr. pravilnik, 1/2013 i $5 / 2014$.

Someren, van M. W., Barnard, Y. F., Sandberg, J. A. C. (1994). The think aloud method. A practical guide to modelling cognitive processes. London: Academic Press. 
Topalov, J. (2012). "Strategije čitanja na engleskom jeziku kod studenata kvantitativna analiza", u Strategije i stilovi u nastavi engleskog jezika, ur. B. Radić-Bojanić (Novi Sad: Filozofski fakultet): 27-40.

Vandergrift, L. (1997). "The strategies of second language (French) listeners". Foreign Language annals 30 (3): 387-409.

Vandergrift, L. (2003). "Orchestrating strategy use: Toward a model of the skilled second language listener". Language learning 53 (4): 463-496.

Votls, I. (2012). "Strategija samoregulacije u razvoju veštine pisanja", u Strategije i stilovi u nastavi engleskog jezika, ur. B. Radić-Bojanić (Novi Sad: Filozofski fakultet): 41-58.

\author{
Bojana R.Crnogorac Stanišljević \\ University of Novi Sad \\ Faculty of Philosophy \\ Doctoral studies - Teaching Methodology
}

\title{
COMPENSATION STRATEGIES IN DEVELOPING THE LANGUAGE SKILL OF LISTENING IN TEACHING THE ENGLISH LANGUAGE - QUALITATIVE RESEARCH
}

\section{Summary}

Listening comprehension as a language skill involves processes that require great mental effort. Nevertheless, the use of language strategies, especially compensation strategies, helps students develop this skill. This paper offers an analysis and interpretation of research findings, whose subject refers to the examination of primary school students' use of compensation strategies in developing the listening comprehension skill in the context of learning English as a foreign language.

The first part of the paper deals with the importance of developing the listening skill and usefulness of compensation strategies. The second part provides a detailed description of strategies within the theoretical framework of the cognitive learning theory. The third part provides a review of recent studies on the subject. The fourth part refers to the research methodology, the fifth refers to the research results, the sixth part is discussion and the seventh part is conclusion.

The research has been conducted on the sample of 7 sixth-grade students of primary school with advanced knowledge of English. The aims of the research have been to determine the students' familiarity with compensation strategies, as well as to discover whether and how the students use them while solving concrete tasks of listening comprehension. The author has used the methods of interview and think-aloud protocol for data collecting. The interview and think-aloud protocol have been analysed qualitatively. The results of the interview with 7 students with advanced knowledge of English show that they use compensation strategies, but they are not aware of that and they do not know how much the strategies can help them in mastering the listening skill. In the end, the findings of the think-aloud protocol show that 7 students mentioned above mostly use the second subgroup of compensation strategy of guessing intelligently: use of other clues (general 
background knowledge and personal experience). The pedagogical implications of this paper would refer to the training of students on compensation strategies so as to develop the listening comprehension skill.

Key words: compensation strategies, listening skill, qualitative research, teaching English.

Primljeno: 22. 3. 2018.

Prihvaćeno: 15. 7. 2018. 